\title{
KANDUNGAN BAHAN ORGANIK PADA SEDIMEN DI PERAIRAN TELUK BUYAT DAN SEKITARNYA
}

\author{
Hermanto W.K. Manengkey \\ Staf Pengajar pada Program Studi IImu Kelautan, \\ Fakultas Perikanan dan IImu Kelautan. UNSRAT. Manado 95115.
}

\begin{abstract}
Information on water conditions, such as sedimentation, physical factors, and coral reef ecosystem, needs to be understood that the stakeholders could optimally utilize the area. This study was aimed to measure the organic content in the sediment from Buyat Bay and its surroundings. The results showed that the terrestrial sediments had higher percentage of organic content than those of the surrounding waters.
\end{abstract}

\section{Keywords: Sediment, coral reef ecosystem, Buyat Bay.}

\section{PENDAHULUAN}

Pantai adalah daerah bertemunya daratan dan lautan. Luas daerah pantai bervariasi tergantung dari jaraknya dan ditentukan oleh keadaan geografi setempat, vegetasi yang ada, adat istiadat masyarakat dan budaya. Pantai lazimnya menggambarkan sebagian proses-proses laut seperti pasang surut ataupun arus.

Pembangunan yang merupakan suatu proses perubahan untuk meningkatkan taraf hidup manusia tidak terlepas dari aktivitas pemanfaatan sumberdaya alam. Di dalam aktivitas ini sering dilakukan perubahan-perubahan pada sumberdaya alam. Perubahan-perubahan yang dilakukan tentunya akan memberikan pengaruh pada lingkungan hidup. Makin tinggi laju pembangunan, makin tinggi pula tingkat pemanfaatan sumberdaya alam dan makin besar perubahan-perubahan yang terjadi pada lingkungan hidup. Oleh karena itu, dalam perencanaan pembangunan pada sistem ekologi yang berimplikasi pada perencanaan penggunaan sumberdaya alam, perlu diperhatikan kaidah-kaidah ekologis yang berlaku untuk mengurangi dampak negatif yang merugikan bagi kelangsungan pembangunan itu sendiri secara menyeluruh (Bengen, 2000).

Semakin menipisnya sumberdaya alam dan menurunnya kemampuan ekosistem alam dalam menyediakan jasa-jasa lingkungan bagi keperluan pembangunan dan kehidupan manusia, mendorong semua bangsa di dunia untuk menerapkan paradigma baru, yaitu pembangunan berkelanjutan (sustainable development). Pembangunan dengan konsep pengelolaan ekosistem sumberdaya alam secara berkelanjutan mengacu pada upaya pemanfaatan ekosistem sumberdaya alam secara optimal dan diimbangi dengan tindakan konservasi secara berkelanjutan. Pengelolaan yang dimaksud menghindari pemanfaatan yang eksploitatif dan melampaui ambang batas daya dukung ekosistem sumberdaya tersebut. Sebaliknya menjaga kelestarian ekosistem tersebut merupakan nilai tambah tersendiri bagi penduduk setempat secara khusus dan masyarakat luas secara umum (Kusumastanto dan Meilani, 1998).

Sebagian besar perairan Buyat memiliki dasar laut berupa pelapisan sedimen yang terbentuk akibat adanya aliran Sungai Buyat yang bermuara di sudut Barat Laut perairan tersebut. Sedimen-sedimen asal daratan yang terbawa oleh aliran mengendap terutama di lereng dekat pantai dan di lereng-lereng bawah bercampur dengan material tailing serta sedimen-sedimen laut lainnya. Relief lokal sepanjang 1-3 m tampak lereng-lereng yang lebih terjal di perairan Buyat dan kemungkinan diakibatkan oleh erosi dan longsor laut alami (Sompie, dkk. 2001).

Kawasan perairan Teluk Buyat dan sekitarnya merupakan suatu kawasan yang dihuni oleh beberapa biota (ikan maupun moluska) sebagai tempat mencari makan, berlindung maupun tempat bertelur. Namun 


\section{Kandungan Bahan Organik pada Sedimen}

kawasan ini akan menjadi kurang nilainya jika untuk mencari makan, berlindung maupun bertelur bagi biota di kawasan tersebut hancur atau rusak.

Kebanyakan erosi pantai akibat aktivitas manusia adalah pembukaan hutan pesisir untuk kepentingan pemukiman, pembangunan infrastruktur dan perikanan tambak, sehingga sangat mengurangi fungsi perlindungan terhadap pantai. Disamping itu aktivitas penambangan terumbu karang di beberapa lokasi untuk kepentingan konstruksi jalan dan bangunan, telah memberikan kontribusi penting terhadap erosi pantai, karena berkurangnya atau hilangnya perlindungan pantai dari hantaman gelombang dan badai.

Kemudian menurut Bengen (2002) bahwa penanggulangan pencemaran yang diakibatkan oleh industri dan limbah rumah tangga, sedimentasi akibat erosi dari kegiatan perkebunan, kehutanan dan limbah pertanian tidak hanya dilakukan di kawasan pesisir saja, melainkan harus dilakukan mulai dari sumber dampaknya. Oleh karena itu, pengelolaan di wilayah ini harus diintegrasikan dengan wilayah daratan dan laut serta Daerah Aliran Sungai (DAS) menjadi satu kesatuan dan keterpaduan pengelolaan. Pengelolaan yang baik di wilayah pesisir akan hancur dalam sekejap, jika tidak diimbangi dengan perencanaan DAS yang baik pula. Keterkaitan antar ekosistem yang ada di wilayah pesisir harus selalu diperhatikan.

Penelitian ini dilakukan untuk mengukur kandungan bahan organik yang terdapat pada sedimen di perairan teluk Buyat dan sekitarnya. Sehingga dengan mengetahui jumlah kandungannya, penyebabnya dapat diketahui.

Upaya pemanfaatan sumberdaya pantai akan selalu menimbulkan persilangan pendapat mengenai dampak negatif yang timbul dari pemanfaatan wilayah tersebut. Di satu ekstrim, mereka menginginkan agar wilayah pantai/pesisir tersebut bebas dari pengaruh manusia, dan dibiarkan sebagaimana adanya. Di ekstrim lain, mereka ingin memanfaatkan semaksimal mungkin sumberdaya pantai yang ada tanpa menyadari kerusakan yang ditimbulkan (Pariwono, 1996).
Dijelaskan oleh Duxbury and Duxbury (1993) sedimen sebagai kumpulan partikel-partikel organik dan anorganik yang terakumulasi secara luas dan bentuknya tak beraturan. Sekitar $70,8 \%$ permukaan bumi ditutupi oleh laut, bagian muka bumi yang sangat luas ini merupakan lingkungan tumpahan material-material sedimen yang terjadi secara fisika, kimiawi, maupun organik yang satu sama lain akan berinteraksi membentuk berbagai macam variasi sedimen (Kaharuddin, 1994). Selanjutnya Davis (1991) menyatakan sedimen yang menutupi dasar perairan memiliki berbagai variasi dalam bentuk partikel komposisi ukuran, sumber atau asal sedimen.

Dalam klasifikasi sedimen, kelompok sedimen lithogenous dan biogenous yang mendominasi daerah pantai. Sebanyak $90 \%$ dari total sedimen yang berada di daerah pantai berasal dari erosi daratan dan berupa sedimen lithogenous yang disebut klastik (Pethick, 1997). Kehadiran dari sedimen biogenous karena terumbu karang yang berkontribusi nyata di sejumlah kawasan daerah pantai.

Material sedimen yang terdeposisi di daerah pantai dan laut dalam dikontrol oleh dua faktor. Faktor tersebut adalah transpor material pelapukan di daratan ke laut dan transpor yang terjadi di dalam laut itu sendiri (Riley dan Chester dalam Djamaluddin, 1993). Proses pergerakan butiran sedimen menyusur pantai ditimbulkan oleh gerakan orbital gelombang yang menyebabkan sedimen bergerak bolak-balik dalam keadaan suspensi tanpa terjadi perpindahan. Terjadinya perpindahan atau pengangkutan sedimen bila ada arus yang bekerja dan arahnya mengikuti arah arus tersebut (Bagnold dalam Thornbury, 1964).

Dasar laut merupakan daerah yang luas dan pada daerah ini mengandung material skeletal. Milyaran mikroorganisme berada dan hidup pada permukaan dasar laut, di sini mereka berkembang, melakukan reproduksi, sampai akhirnya mati. Bagian-bagian tubuh organisme akan terakumulasi dan tersebar secara luas pada dasar laut (Ingmanson and Wallace, 1989).

Menurut Pariwono (1996), bahan organik merupakan pencemar perairan yang paling umum dijumpai, dan dampak yang ditimbulkannya tidak langsung. Masalah 
yang ditimbulkannya adalah menurunkan kandungan oksigen terlarut dan terjadi proses eutrofikasi (proses bertumbuh-kembangnya organisme perairan karena kesuburan yang meningkat dan biasanya mempunyai dampak negatif terhadap ikan).

Sedimen yang berasal dari hancuran bahan-bahan organik dari hewan maupun tumbuhan yang sudah mati, disebut juga sedimen organik atau sedimen organogen atau biolit (Setiono, 1996 dalam Kohongia, 2002). Secara umum, pendeposisian material organik karbon dan keadaannya (material yang bersumber dari cangkang dan karang) lebih banyak terdapat di daerah dekat pantai dan pada lingkungan laut lepas (Stein, 1991 dalam Kohongia, 2002).

\section{METODE PENELITIAN}

Data yang dikumpulkan yaitu diperoleh secara langsung di daerah penelitian dengan cara observasi (pengamatan). Kegiatan yang dilakukan dalam penelitian ini adalah pengukuran sedimen dengan menggunakan sediment trap. Lokasi penelitian berada di perairan Teluk Buyat dan sekitarnya.

Dalam pengukuran sedimen dimana terlebih dahulu sudah menempatkan sediment trap pada 8 stasion, kemudian mengambilnya dengan selang waktu 1 minggu atau 2 minggu (tergantung keadaan cuaca) secara berkesinambungan. Khusus untuk stasion 3 dekat dengan muara sungai digunakan 2 buah sediment trap yaitu 1 menghadap ke laut (3A) dan satu lagi menghadap ke arah muara sungai (3B). Sediment trap yang digunakan mempunyai panjang $11,5 \mathrm{~cm}$, diameter $(\varnothing) 5 \mathrm{~cm}$, dan diletakkan $20 \mathrm{~cm}$ dari dasar. Selanjutnya penempatan sediment trap yaitu dengan menggunakan alat bantu berupa pipa diletakkan pada balok beton di permukaan dasar perairan antara koloni karang kecuali stasion 3 karena tidak ada karang. Konstruksi dari sediment trap ini mengacu pada Gardner, (1980) dalam English, et al. (1997). Selanjutnya kedalaman yang diletakkan alat ini yaitu berkisar 3-4 m.

Perlakuan untuk mendapatkan kandungan bahan organik yaitu sampel yang ada diambil dengan 2-3 kali ulangan. Cara perlakuannya adalah sebagai berikut:
1. Sampel dimasukkan ke dalam cawan keramik dengan berat setiap cawan sudah diketahui sebelumnya;

2. Mengeringkan sampel pada oven pengering selama 10 jam dengan suhu $90^{\circ} \mathrm{C}$, selanjutnya dilakukan penimbangan (mengawali pelaksanaan penimbangan sampel terlebih dahulu didinginkan dalam dessicator serta mencatat hasilnya (berat awal);

3. Sampel dimasukkan dalam oven pembakar selama 5 jam pada suhu $500^{\circ} \mathrm{C}$ (Delgado, et. al. 1991), selanjutnya didinginkan dalam dessicator, kemudian dilakukan penimbangan untuk mendapatkan berat akhir (setelah pembakaran).

\section{HASIL DAN PEMBAHASAN}

Dalam melakukan pengujian jumlah kandungan bahan organik dari setiap stasion tidak semuanya dapat dilakukan, hal ini dikarenakan bahwa jumlah sedimen yang berada pada setiap sediment trap tersebut kurang (sedikit). Untuk kandungan bahan organik yang diperoleh tersebut menunjukkan persentasi tertinggi ditemukan pada stasion 3B sebanyak $20,70 \%$, dan diikuti dengan stasion 2 yaitu sebanyak $14,31 \%$, stasion $3 \mathrm{~A}$ sebanyak $11,13 \%$, dan jelasnya sebagaimana diperlihatkan pada Gambar 1.

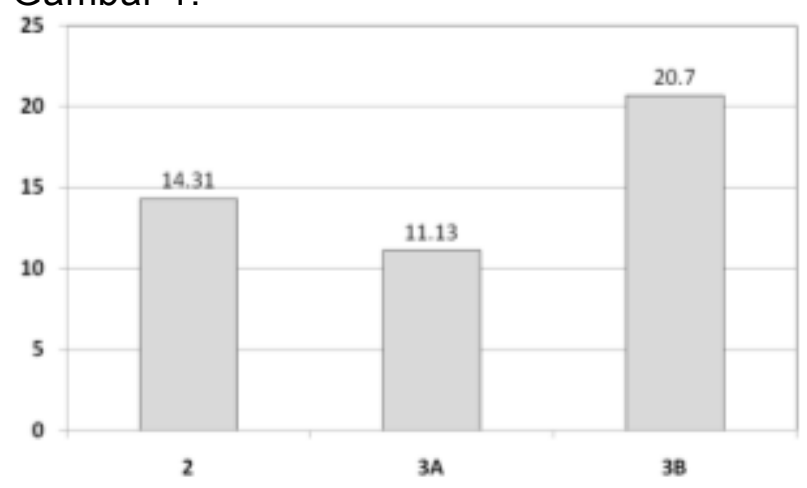

Gambar 1. Grafik persentasi (\%) kandungan bahan organik di sedimen pada setiap stasion pengambilan I (pertama) dengan waktu 2 minggu.

Pada Gambar 1 (pengambilan I) memperlihatkan bahwa persentasi kandungan bahan organik yang terbanyak pada stasion $3 \mathrm{~B}$ yang berada di daerah teluk yang menghadap ke muara sungai. Jadi dapat dijelaskan bahwa sumber sedimen berasal dari daratan dan untuk yang ditemukan 
pada stasion 2 yang berada di luar Teluk Buyat lebih banyak dengan stasion 3A (daerah muara sungai tapi menghadap ke laut), hal ini diduga sedimen tersebut terbawa oleh massa air karena bongkaran dari gelombang dan selanjutnya diangkut arus walaupun jaraknya tidak jauh dari muara sungai.

Kemudian hasil yang diperoleh pada pengambilan II, menunjukkan bahwa persentasi tertinggi ditemukan pada stasion 3B sebanyak $16,09 \%$ dan diikuti dengan stasion 4 yaitu sebanyak $13,54 \%$, stasion $3 A$ sebanyak $10,18 \%$ dan jelasnya sebagaimana diperlihatkan pada Gambar 2.

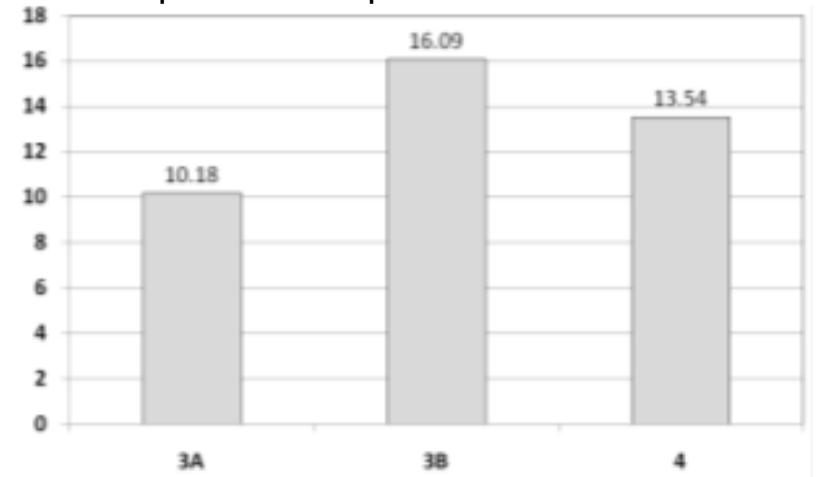

Gambar 2. Grafik persentasi (\%) kandungan bahan organik di sedimen pada setiap stasion pengambilan II (kedua) dengan waktu 1 minggu.

Pada Gambar 2 ditemukan bahwa persentasi kandungan bahan organik masih didominasi oleh stasion $3 \mathrm{~B}$ yaitu sediment trapnya menghadap muara sungai, namun jika dibandingkan antara stasion 3A yang sediment trapnya menghadap ke laut lebih sedikit dengan stasion 4 yang sama-sama berada di dalam teluk, mengartikan bahwa sedimen yang berada di dalam teluk lebih banyak pada daerah stasion 4 . Hal dibuktikan dengan arah arus di dalam teluk umumnya mengarah ke arah utara.

Dapat dijelaskan juga bahwa kandungan bahan organik berasal dari daratan, dan hal ini juga yang ditemukan pada pengambilan pertama.

Kemudian hasil yang diperoleh pada pengambilan III, menunjukkan bahwa persentasi tertinggi ditemukan pada stasion 4 sebanyak $14,87 \%$, dan diikuti dengan stasion 2 yaitu sebanyak $13,13 \%$, stasion 1 sebanyak $11,97 \%$, stasion $3 A$ sebanyak $9,26 \%$ dan $3 \mathrm{~B}$ sebanyak $9,14 \%$, jelasnya diperlihatkan pada Gambar 3.
Gambar 3 memperlihatkan bahwa persentasi kandungan bahan organik pada stasion 1 dan 2 (11,97\% dan 13,13\%) lebih banyak jika dibandingkan dengan stasion $3 \mathrm{~A}$ maupun 3B yaitu hanya $9,26 \%$ dan $9,14 \%$ yang terdapat di dalam teluk dan juga dekat dengan muara sungai, hal ini diduga karena daerah stasion 1 dan 2 sudah berada dekat dengan lahan pertanian sehingga material sedimen tersebut langsung ke laut dan dibongkar oleh gelombang yang selanjutnya ditranspor oleh arus ataupun arus pasut. Kemudian untuk stasion 4 yang prosentasinya yaitu $14,87 \%$ lebih banyak dengan stasion 3 dimana sama-sama berada di dalam teluk, hal ini dikarenakan bahwa proses pergerakan massa air yang berada di dalam teluk oleh arus pasut umumnya mengarah ke daerah stasion 4 , lagipula dibuktikan dengan banyaknya sampahsampah yang mengendap di daerah tersebut.

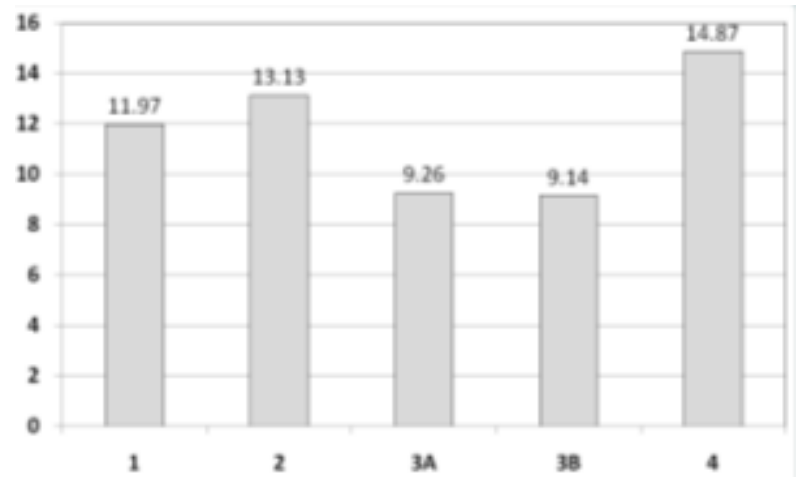

Gambar 3. Grafik persentasi (\%) kandungan bahan organik di sedimen pada setiap stasion pengambilan III (ketiga) dengan waktu 2 minggu.

Hasil yang diperoleh seperti pada pengambilan IV, menunjukkan bahwa persentasi tertinggi ditemukan pada stasion 4 sebanyak $12,17 \%$, dan diikuti dengan stasion 3A dan 3B yaitu sebanyak 10,84\% dan $9,71 \%$, stasion 2 sebanyak $9,57 \%$, jelasnya sebagaimana diperlihatkan pada Gambar 4. 


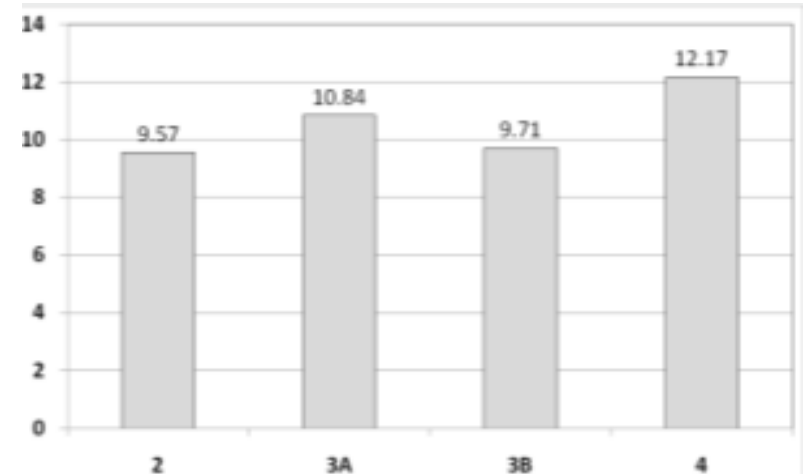

Gambar 4. Grafik persentasi (\%) kandungan bahan organik di sedimen pada setiap stasion pengambilan IV (keempat) dengan waktu 1 minggu.

Pada Gambar 4 memperlihatkan bahwa persentasi kandungan bahan organik paling banyak terdapat pada stasion 4 jika dibandingkan dengan stasion yang lain. Hal ini sama dengan yang terjadi pada pengambilan III yaitu diduga bahwa material sedimen yang terdeposisi ke daerah stasion 4 tersebut karena pengaruh dari pergerakan massa air yang mengarah ke daerah tersebut. Dapat dijelaskan juga bahwa pada stasion $3 \mathrm{~A}$ yang menghadap ke laut persentasi kandungan bahan organiknya lebih banyak dengan stasion 3B yang menghadap ke arah muara sungai, sehingga diduga bahwa sedimen yang sifatnya masih melayang di laut namun berasal dari darat mengarah ke arah utara dalam teluk tersebut.

Kemudian hasil yang diperoleh seperti pada pengambilan $\mathrm{V}$, menunjukkan bahwa persentasi tertinggi ditemukan pada stasion 1 sebanyak $14,17 \%$ dan diikuti dengan stasion $3 A$ yaitu sebanyak $13,01 \%$, stasion 4 sebanyak $12,70 \%$, stasion 2 sebanyak $11,76 \%$ dan 3B sebanyak $10,36 \%$, jelasnya diperlihatkan pada Gambar 5 .

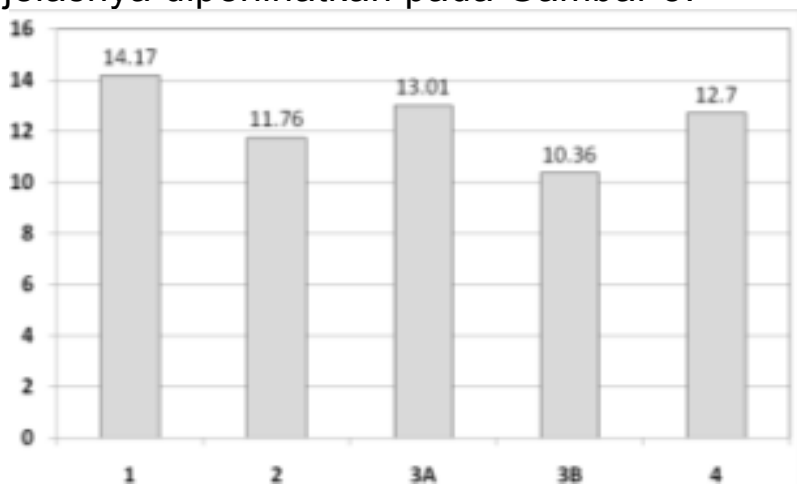

Gambar 5. Grafik persentasi (\%) kandungan bahan organik di sedimen pada setiap stasion pengambilan $\mathbf{V}$ (kelima) dengan waktu 2 minggu.
Pada Gambar 5 memperlihatkan bahwa persentasi kandungan bahan organik paling banyak ditemukan pada stasion 1 dan hal ini diduga karena terjadi pengangkutan material sedimen oleh arus pasut yang mengarah ke arah Barat di wilayah perairan tersebut karena pada stasion 5-8 tidak ditemukan kandungan bahan organik lagipula sedimen yang ditemukan pada daerah tersebut banyak berasal dari bongkahan karang (biogenous). Dapat dijelaskan juga bahwa pergerakan massa air yang terjadi di daerah tersebut sering berubahubah dengan jangka waktu yang tidak lama dan hal ini diduga pengaruh dasar perairan yang tidak curam dan juga pengaruh arus pasut.

Berdasarkan dari hasil persentasi kandungan bahan organik yang diperoleh dari setiap stasion, menunjukkan bahwa jumlah yang paling banyak yaitu stasion 3B yaitu $20,70 \%$ yang berada dekat muara sungai dan menghadap ke arah muara sungai (Teluk Buyat), dan ini terjadi pada pengambilan I. Perlu diketahui juga bahwa sebelum pengambilan I, berlangsung musim hujan, sehingga terindikasi bahwa sedimen-sedimen tersebut berasal dari daratan baik itu lahan pertanian maupun limbah yang dibuang oleh masyarakat setempat melalui sungai dan ada yang langsung ke laut.

Hasil ini juga dibuktikan dengan hasil dari wawancara dengan beberapa masyarakat setempat dimana bentuk pengolahan pertanian masih bersifat tradisional yaitu tidak memperhatikan apakah bentuk lereng agak curam ataupun landai itu sama saja yang pasti akan mendapatkan hasil sehingga apakah akan terjadi erosi atau tidak para petani tidak mengetahuinya, selanjutnya informasi dari beberapa petani bahwa mereka juga menggunakan pupuk untuk pertanian seperti pupuk Urea, dan yang umum menggunakan NPK (Natrium, Phosphat dan Kalium), begitu juga dengan sampah yang langsung dibuang apakah ke sungai atau ke laut mereka tidak mengetahui dampak yang akan terjadi oleh sampah tersebut, namun ada juga beberapa masyarakat yang sampahnya ditimbun ataupun langsung dibakar. 


\section{KESIMPULAN}

Kandungan bahan organik dalam sedimen terbanyak 20,70 \% ditemukan pada stasion 3B pada pengambilan I, yaitu yang berada di dalam teluk dan menghadap ke arah muara sungai.

Kandungan bahan organik dalam sedimen diduga berasal dari sampah rumah tangga, dan bahan anorganik berasal dari lahan atas.

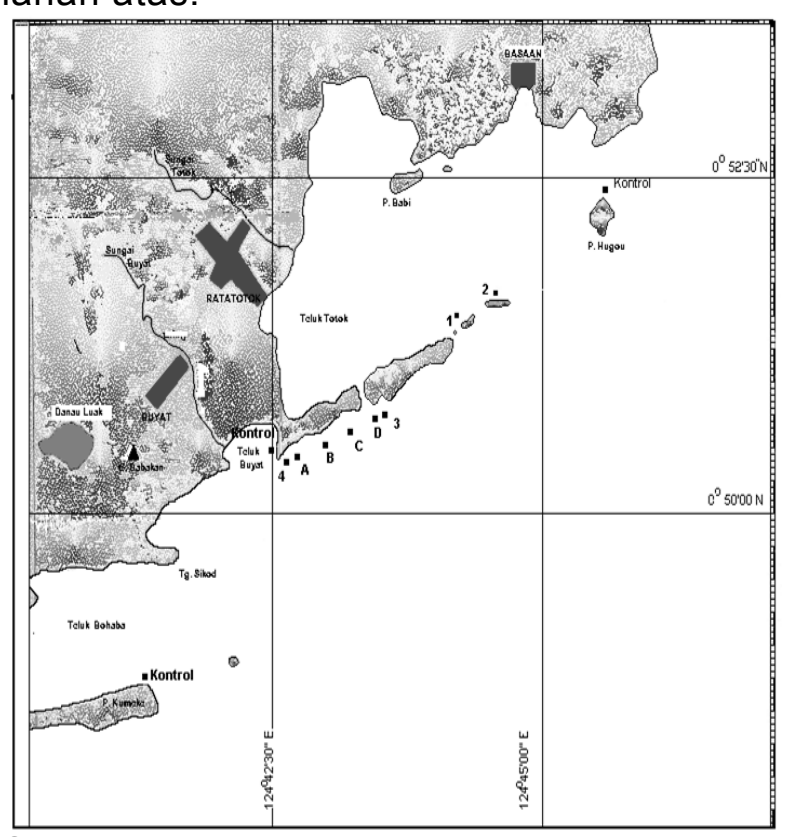

Gambar 6. Peta lokasi penelitian daerah Teluk Buyat dan sekitarnya.

\section{DAFTAR PUSTAKA}

Bengen, D.G., 2000. Ekosistem dan Sumberdaya Alam Pesisir. Sinopsis. Pusat Kajian Sumberdaya Pesisir dan Lautan. Institut Pertanian Bogor.

Bengen, D.G., 2002. Konsep Pengelolaan Wilayah Pesisir Terpadu Berbasisi Ekosistem dan Masyarakat. Makalah disampaikan dalam Pelatihan Pengelolaan Wilayah Pesisir Terpadu (Manado 16-21 September 2002).

Davis Jr., A.R., 1991. Oceanography: An Introduction to the Marine Environment. Wm. C. Brown Publishers. lowa. USA.

Delgado, M., V.N de Jonge dan H. Peletier. 1991. Experiments on Resuspension of Natural Microphytobenthos Populations. Marine Biology 108:321-328.
Djamaluddin, R., 1993. Sifat Fisika Kimia Sedimen di Laut. Tesis. Program Pascasarjana IPB. Bogor.

Duxbury, A.B. and A.C. Duxbury, 1993. Fundamental of Oceanography. Wm. C. Brown Publ. Washington.

English, S., C. Wilkinson, and V. Baker, 1997. Survey Manual for Tropical Marine Resources $\left(2^{\text {nd }}\right.$ Edition). Australian Institute of Marine Science. Townsville.

Ingmanson, D.E. dan W.J. Wallace, 1989. Oceanography: An Introduction. Fourth edition. Wadsworth Publishing Company Belmont. California.

Kaharuddin., 1994. Marine Sediment and Preparation. Program Studi Ilmu dan Teknologi Kelautan, Universitas Hasanudin. Ujung Pandang.

Kohongia, K., 2002. Karakteristik Sedimen Dasar Teluk Buyat. Skripsi. Program Studi IImu Kelautan. Fakultas Perikanan dan IImu Kelautan-Unsrat. Manado.

Kusumastanto, T. dan M.M. Meilani, 1998. Economic valuation of mangrove resources in Subang, West Java, Indonesia. The Regional Workshop on Partnership in Application of Integrated Coastal ManagementChonburn, Thailand.

Pariwono, J.I., 1996. Oseanografi Fisika dan Dinamika Perairan Pesisir. Materi Pelatihan Perencanaan dan Pengelolaan Wilayah Pesisir Secara Terpadu (ICZPM). PKSPLLP IPB kerjasama dengan Dirjen BANGDA-DEPDAGRI. Bogor.

Pethick, J., 1997. An Introduction to Coastal Geomorphology. Edward Arnold. London.

Sompie, D., J. Kojansow, D. Laneawicz, G. Mamuaya, 2001. Menentukan Ketebalan Pengendapan Tailing Dengan Pengukuran Bathymetry. Dipresentasikan pada Pertemuan IImiah Nasional ISOI (Jakarta 29-31 Mei 2001).

Thornbury, W.D., 1964. Principles of Geomorphology. By John Wiley and Sonc. Inc. 